\title{
Group Investigation Modelin Teaching and LearningWriting for Secondary Level Students
}

\author{
Yepi Sedya Purwananti \\ The Institute of Teacher Training and Education \\ (STKIP) PGRI Tulungagung \\ yepisedya@gmail.com
}

\begin{abstract}
Group investigation is able to make the students involved from the planning, writing, until the completing of writing, both in determining the topic as well as a way to learn through investigation. One thing that differentiates it from other cooperative learning model is the model has a major focus group investigation of an object or topic to write. The investigation has provided opportunities for students to argue, think critically, do the findings and analyze collaboratively. The use of this model will also allow students to achieve success in learning, thinking skills and social skills. This learning model allows students to develop the knowledge, abilities, and skills totally in a learning environment that is open and democratic. Students are no longer as an object of learning, but can also act as tutors for their peers. The application of the model group investigation in writing class that implements the practice of speaking directly, authentic and natural is in line with efforts to improve and develop characters. Natural context in learning writing makes the learning process designed more meaningful. Learning to write by using a theoretical model of group investigations involving students in planning, exploring and sharing ideas. Students are encouraged to collaborate with friends and learn the "how" of their own in accordance with the cognitive style of each. Students empowered as the learners are able to argue, work hard, share, help peers, and have affection to friends.
\end{abstract}

Keywords: Learning Model, Investigation Group, Writing Skills.

\section{INTRODUCTION}

As one of the international languages which is known and used by most people in the world, English is very important to be learned and mastered. It is hoped that students will be able to communicate in English.Language is an important tool for communication. There are two kinds of communication. Verbal and nonverbal communication, verbal communication means spoken and written forms, and nonverbal communications for example are gesture and body language. It means to understand, learn, think, socialize, and express many ideas, information, feelings, and also develop science, technology, and culture between speakers and listeners or writers and readers. Therefore, communicationbegan tobe taughtatelementary level. 
Based on the of Minister of Educational and culture's decree No: 372/2003 dated December 12, 2003 stated that English becomes the first foreign languageand compulsory subject that should be taught in Indonesian school starting from Junior High School up to university level. English consists of four skills that should be learned; they are listening, speaking, reading, and writing. Writing is one of language skills in English that plays an important role in our life and it can be practiced and mastered. In many ways, it is like driving a car. If you have ever driven in another country, you know that some of the rules of the road may be different(Muh. Barid Nizarudin Wajdi, 2016). Just as the rules for driving differ from country to country, the conventions for writing may change from language to language.

According I. S. P Nation (2009: 113), "Writing is an activity that can usefully be prepared for by work in the other skills of listening, speaking and reading". "Writing is a progressive activity" said Oshima (1998: 1). This means that when you first write something down, you have already been thinking about what you are going to say and how you are going to say it. This skill becomes more difficult for students in any level of English because it needs hard thinking and procedure word sentences, paragraph at the same time(Ummah \& Wajdi, 2016). Besides that, many students who study English consider that they do not know how to write a topic. They are unable to apply English in the written form. They often face some problems to organize their ideas they do some mistake with the lack of knowledge in vocabularies and grammatical rules and tenses.

Moreover, the students face some problems in improving their writing skill. They cannot recognize or improve a sentence or paragraph correctly or they do not have an idea about what they want to write. Furthermore they cannot put the right words down becoming a good sentence or paragraph. Another problem is, although they have an idea, but they are still confused how to develop it as the correct one, so they cannot make a good paragraph(Muh Barid Nizaruddin Wajdi, 2016). These problems can be influenced by some factors that these are coming from internal and external of students. The internal factors that can affect the students' writing are IQ, cognitive ability, talent, and motivation. And the external factors that can affect the students' writing are curriculum, material, approach, method, strategy, and technique. So that teacher should be creative in choosing the strategies for teaching.

\section{Relationship between Learning Writing, Social and Cognitive.}

Writing skills competence, as one aspect of language skills plays a very important and strategic. It can be observed from every discipline requires writing activities. As stated by Cleary and Linn (1993: 253) that writes and reads very important role in learning in any discipline academic. Writing is one of the most organized and effective way to express the idea meaningful to others. The author can express his 
ideas systematically, revise, and refine the results so that the information disclosed writings can be better and understood by the reader.

The ability or writing skills are also seen as complex capabilities. This is evident in the statement Raimes (1983: 6), that in the skills of writing there are a number of components that must be faced by a writer. These components are an understanding of (1) the purpose of writing, (2) the prospective reader, (3) the content, (4) the process of writing, (5) diction, (6) aspects of the organization, (7) grammatical, and (8) writing techniques. These eight aspects which are the real picture of the complexity of writing skills.

Furthermore Heaton (1998: 135) states that there are five skills necessary to prepare a good essay. The five skills in question is (1) grammatical skills (ability to form correct sentences); (2) pouring the content, (3) Stylistics skills (ability to use words and language are effective); (4) mechanical skills (ability to use proper spelling and punctuation); and (5) decides skills (ability to write in a way that is appropriate for the purpose and special readers along with the ability to select, organize, and sort relevant information).

The development of writing skills, as well as oral language skills, requires an understanding of how to combine the components of language (example: The knowledge of vocabulary, grammar, orthography, and the structure of the kind of writing) in order to produce a text. In writing, a writer must make a proper analysis of the topics that will be written to the actual, attractive desirable and understood the reader. This statement is in line with the concept Nystrand (1982: 64-65) that the writing was significantly requires authors to pay attention to some limitations that could affect the way the reader understand the meaning of the text. Furthermore, there are five restrictions stated in question, (1) the graphical limitations, (2) syntax, (3) semantic restrictions, (4) limits the texture, and (5) contextual constraints.

The Graphical limits emphasis on aspects of orthography, the clarity of handwritten or printed, punctuation, in order to use space and layout. A syntactic restriction focuses on the author's understanding of the structure of the sentence, the ambiguity in the use of a vocabulary. Semantic restrictions related to the author's understanding of the meaning, the meaning contained in the essay. Limitation of textures that use the means of cohesion that can explain and maintain continuity of meaning in the essay. Contextual limits, the factors such as formatting, text type, style, typeface and titles relevant to the essay. It can be concluded, writing skills a person's ability to express ideas, opinions, thoughts, and feelings to others through written language(Ifit Novita Sari, 2015).

Writing in the context of learning requires learners to apply a wide range of abilities and language skills, including knowledge of textual and knowledge about what the objectives of the communication of an essay. Writing process often begins 
with planning, followed by a stage of writing the initial draft, writing and revision stage(Sari, 2017).

Learning writing in accordance with the modern approach is learning not only emphasize on the product, but also the process (Nunan, 1991: 86; Tompkins, 2012: $7)$. In the activity, the students can feel direct experience in writing activities. Thus, students and teachers should realize that writing was a gradual process. Therefore, in the learning writing, teachers should prepare students to understand the condition of learning how to write and not just learning to write. The basic concept of this approach gives an opportunity to the students to not rely entirely on the teacher, but more than that the student should also be responsible for writing and able to collaborate with other students. Thus the teacher acts as a facilitator, motivator, and organizers in creating an atmosphere that is conducive to learning to write.

Another modern paradigm of learning writing state that the writing is a social activity (Nunan, 1991: 87). This concept illustrates that in writing; the students can work together and collaborate with others so that the act of writing seems more dynamic and meaningful. Cooperation that can be done, among others, in the form, the investigation group (group-investigation). Implementation of this cooperation is directly formed a variety of skills in students, including skilled argue, ask, listen, and arguing with peers. Students are trained in respect of various opinions and ideas from friends. In this context, the child is seen as a writer who grew up in the midst of a social community. In accordance opinions Halliday (in Reid, 1993: 16) states that the child as the author is part of the social community and children construct meaning in a social context. Thus, the potential of the students can grow and develop naturally.

Learning writing is also directly associated with cognitive competence. Cognitive competence of students emerging from its cognitive style. Therefore, before learning starts teachers should also pay attention to students' cognitive styles. The importance of considering the cognitive styles of students in learning activities are also proposed by Dunn and Dunn (1999: 79) that the cognitive styles of students should be taken into consideration when learning activities designed for students. Furthermore it is said that the cognitive styles can be used to predict the type of learning the most effective method possible. Cognitive style refers to how individuals process information and use strategies to respond to the tasks. Cognitive style is a consistent trend and characteristics of individuals in receiving, remembering, organizing, processing, thinking, and problems solving. Golstein\& Blackman (in Faiola and Matei, 2009) suggests that cognitive style is typical ways in which people: (1) is conceptually organize their environment and (2) spontaneously filter and process environmental stimuli so that it can be psychologically meaningful. 
According to Witkin (1977: 64), cognitive styles are forms of functioning of the typical manner by a person's intellectual ability displayed in the activities of perceptual and intellectual activities. Keefe (1987: 77) suggests that cognitive style is part of the learning style that depicts the relative behavior habits remain in a person to receive, to think, solve problems and to store information. From the definition, it is known that cognitive style involves a person's intellectual ability to process and store information. Furthermore, the experts have identified various dimensions or cognitive style. One of cognitive style, the field dependence (FD) and field independence (FI).

\section{Shape of Model Investigation Group in Learning Writing.}

Learning writing as one aspect of learning English in less dealt with seriously. In general, students seldom get the material how to write correctly

. Teachers tend to prioritize mastering the material that directly affects student success in working on the final exam or National final examination. In fact, learning to write is a set of complex and difficult process that requires a clear methodological framework of learning at all stages of learning (Knapp \& Watkins, 2005: 14).

Nunan (1999: 271) argued that the writing skill to produce a coherent, good and large is the most difficult skill to learn language skills among others. This statement suggests that learning writing has the highest level of difficulty compared with learning listening, reading, and speaking. Thus, it should be learning writing in elementary school get serious and adequate attention by all parties.

Associated with the statement, the following is the example of teaching steps in writing using Group Investigation model.

\section{TEACHING SCENARIO USING INVESTIGATION GROUP MODEL Learning Objectives}

After completion the student is able to;

1. Noting that the topic sentence in each paragraph in a popular science passage correctly.

2. Writing the main points of popular science passage correctly selected.

3. Assembling the main points of the content of science passage is selected to be a summary of the enhanced attention to spelling.

4. Writing a summary of the contents of the passage selected with due regard to the content, systematic, sentences, and spelling.

5. Assessing summary of the contents of popular science passage written selected appropriately friends.

6. Improving summary of the contents of popular science passage based assessment in accordance with the spelling friend enhanced. 


\section{Learning Materials}

1. Elements Builders paragraph

2. Writing summaries of popular science books
a. Principles of popular books
b . Systematic summary
c. Language summaries of popular books

3. Practicing writing summaries of the books

4. Assessing summaries of the contents of popular science books.

5. Practicing enhance content summary popular science books

\section{Model, Type and Learning Methods}

1. Model

2. Type

3. Method
: Cooperative

: Group Investigation

: Discussion, Questions \& Answers, lectures, inquiry

Steps Learning Activities

\begin{tabular}{|c|c|c|c|}
\hline Stages & Teachers Activities & Students Activities & $\begin{array}{l}\text { Time allocation } \\
\text { ( minute) }\end{array}$ \\
\hline Initial Activity & $\begin{array}{l}\text { a. Teachers open } \\
\text { with greetings and } \\
\text { prepare the } \\
\text { conditions for the } \\
\text { classroom in } \\
\text { learning activities } \\
\text { b. Teachers convey } \\
\text { basic competencies } \\
\text { that must be } \\
\text { achieved by } \\
\text { students } \\
\text { c. The teacher } \\
\text { explained the } \\
\text { activities that will } \\
\text { be carried out } \\
\text { related to the } \\
\text { writing material for } \\
\text { the students. }\end{array}$ & $\begin{array}{l}\text { a. Students pay } \\
\text { attention to the } \\
\text { teacher's explanation } \\
\text { and prepare to learn } \\
\text { b. Pay attention and } \\
\text { think to be able to } \\
\text { achieve the basic } \\
\text { competencies that } \\
\text { have been submitted } \\
\text { by teachers. } \\
\text { c. Pay attention and } \\
\text { ask to relate to the } \\
\text { activities to be } \\
\text { performed. }\end{array}$ & 10 minutes \\
\hline Core Activities & $\begin{array}{l}\text { a. Teachers submit } \\
\text { an explanation the } \\
\text { steps of learning }\end{array}$ & $\begin{array}{l}\text { a. Students observe a } \\
\text { number of popular } \\
\text { science books or }\end{array}$ & 55 minutes \\
\hline
\end{tabular}




\begin{tabular}{|c|c|c|}
\hline $\begin{array}{l}\text { Grouping Stage } \\
\text { (grouping) }\end{array}$ & $\begin{array}{l}\text { activities with } \\
\text { learning model (GI) } \\
\text { models } \\
\text { b. Teachers } \\
\text { establish } \\
\text { investigation group } \\
\text {, with members of } \\
\text { each group of } 4 \text { to } 5 \\
\text { children } \\
\text { heterogeneously }\end{array}$ & $\begin{array}{l}\text { preferred reading and } \\
\text { discuss with the group } \\
\text { about the topics that } \\
\text { are on it. } \\
\text { b. Students join study } \\
\text { groups based on their } \\
\text { chosen topic or book } \\
\text { an interesting read for } \\
\text { investigation }\end{array}$ \\
\hline $\begin{array}{l}\text { Planning Stage } \\
\text { (planning) }\end{array}$ & $\begin{array}{l}\text { a. Teachers and } \\
\text { students identified } \\
\text { a number of } \\
\text { popular science } \\
\text { books or reading } \\
\text { interesting to find a } \\
\text { topic sentence of } \\
\text { each paragraph } \\
\text { and discussed. } \\
\text { b. The teacher } \\
\text { divides the study } \\
\text { group and give } \\
\text { books / literature } \\
\text { to be read and } \\
\text { discussed }\end{array}$ & $\begin{array}{l}\text { a. Students find and } \\
\text { choose a popular } \\
\text { scientific book / } \\
\text { reading which will be } \\
\text { searched topic } \\
\text { sentence in it. } \\
\text { b. Students read } \\
\text { selected books / } \\
\text { reading ( each group } \\
\text { read the book / } \\
\text { reading different ) } \\
\text { c. Students studied } \\
\text { the content of books } \\
\text { read. }\end{array}$ \\
\hline $\begin{array}{l}\text { Phase } \\
\text { Investigation } \\
\text { (investigation) }\end{array}$ & $\begin{array}{l}\text { a. Teachers around } \\
\text { the classroom to } \\
\text { monitor the } \\
\text { activities of student } \\
\text { conduct an } \\
\text { investigation of } \\
\text { selected books or } \\
\text { reading. } \\
\text { b. With teacher } \\
\text { guidance, students } \\
\text { investigate } \\
\text { suit each task to } \\
\text { collect data and }\end{array}$ & $\begin{array}{l}\text { a. Students read and } \\
\text { conduct an } \\
\text { investigation to find } \\
\text { the topic sentence or } \\
\text { main ideas in popular } \\
\text { science books / } \\
\text { reading selected. } \\
\text { b. Students find some } \\
\text { data that is } \\
\text { categorized as a topic } \\
\text { sentence or main } \\
\text { ideas of each } \\
\text { paragraph in the book }\end{array}$ \\
\hline
\end{tabular}




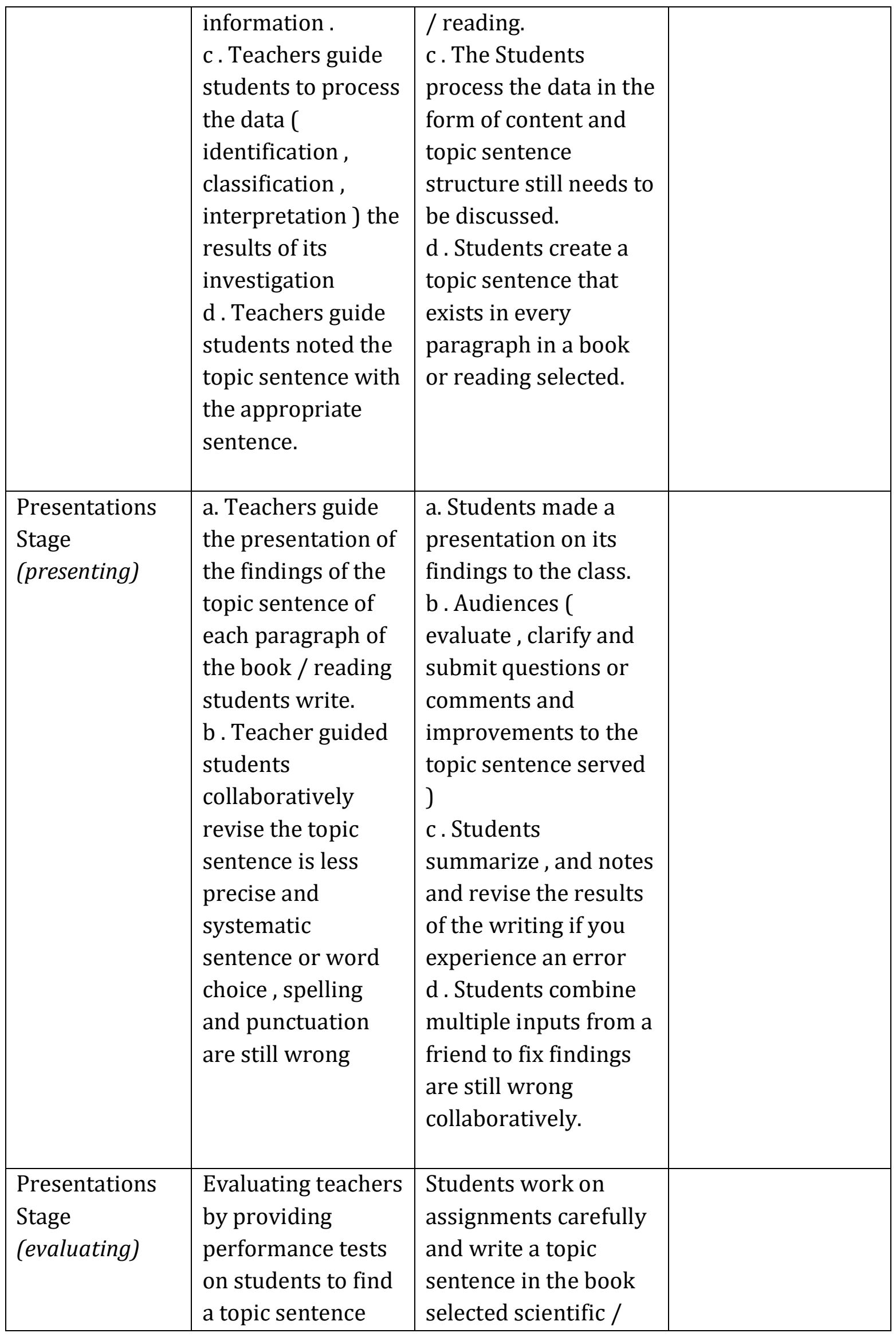




\begin{tabular}{|l|l|l|l|}
\hline & $\begin{array}{l}\text { correctly and put } \\
\text { them into the } \\
\text { appropriate } \\
\text { sentence in } \\
\text { accordance with } \\
\text { the rules }\end{array}$ & interesting reading. & \\
\hline Final Activity & $\begin{array}{l}\text { Teachers close } \\
\text { lesson with } \\
\text { motivating } \\
\text { students to study } \\
\text { hard and } \\
\text { announces the next } \\
\text { meeting students } \\
\text { are required } \\
\text { finding points of } \\
\text { the contents of the } \\
\text { book or reading } \\
\text { correctly }\end{array}$ & $\begin{array}{l}\text { Students pay attention } \\
\text { to the teacher's } \\
\text { explanation }\end{array}$ & minutes \\
& & \\
\hline
\end{tabular}

\section{CONCLUSION}

Group Discussion as one of teaching model in cooperative learning can help students learn writing effectively. Supporting by the cognitive social ability, students will also learn how to work cooperatively to achieve certain objectives in learning. Managing the time, students' learning activities and materials are recommended to be taken into consideration in designing the writing class using Group Investigation.

\section{REFERENCES}

Cleary. L. M. dan Michael D. L. 1993. Linguistics For Teacher's. New York: McGrawHill, Inc.

Dunn, R., \& Dunn, K. 1999. The Complete Guide to the Learning Strategies in service System. Boston: Allyn \& Bacon.

Faiola, A, \&Matei, S.A.2009. Cultural Cognitive Style and Web Design: Beyond a behavioral inquiry into computer-mediated communication. (Hyperlink 
"http://jcmc.indiana.edu/vol1" http://jcmc.indiana.edu/vol1 1/issue 1/faiola.html) taken November $2^{\text {nd }}, 2014$.

Heaton, J. B. 1998. Writing English Language Test. USA: Longman Inc.

Keefe, J. W. 1987. Learning Style Theory and Practice. Virginia: National Association of Secondary School Principals.

Nunan. 1988. Designing Tasks For The Communicative Classroom. Cambridge: University Press.

. 1991. Language Teaching Methodology: A Tex Book for Teachers. New York: Prentice Hall.

Nystrand. 1982. An Analysis of Errors in Written Communication. In M. Nystrand (Ed), What Written Know (pp. 57-74). New York: Academic Press.

Raimes, Ann. 1983. Techniques in Teaching Writing. New York: Oxford University Press.

Reid, Joy M. 1993. Teaching ESL Writing. Prentice Hall Regents.

Tompskins, G. E. 2012. Teaching Writing: Balancing Process and Product. New York: Mac Millan. College Publishing Company.

Witkin, H. A., Moore, C. A., Goodenough, D. R., dan Cox, P. W. 1977. Field Dependent and Field Independent Cognitive Style and Their Education. Review of Educational Research Winter, vol. 47, no. 1. (HYPERLINK "http://www.jstor.org/stable/1169967"

http://www.jstor.org/stable/1169967) taken November 2 ${ }^{\text {nd }}, 2014$.

Ifit Novita Sari, V. (2015). Kurikulum Ideal untuk Indonesia.

Sari, I. N. (2017). Kepemimpinan Moral-Spiritual Guru dalam Pembentukan Karakter Peserta Didik.(Studi Multikasus di Sekolah Dasar Plus Al Kautsar, Sekolah Dasar Negeri Kauman I, dan Sekolah Dasar Katolik Santa Maria II di kota Malang). DISERTASI Dan TESIS Program Pascasarjana UM.

Ummah, Y. C., \& Wajdi, M. B. N. (2016). Dismantling Paradigm Book Ta'limul Muta'allim. Educatio: Journal of Education, 1(2), 1-10. Retrieved from http://www.ejournal.staimnglawak.ac.id/index.php/educatio/article/view/2 6

Wajdi, M. B. N. (2016). Arabic Learning Skill. AT-Tahdzib: Jurnal Studi Islam Dan Muamalah, 3(2), 32-47.

Wajdi, M. B. N. (2016). المناهج التعليمية للغة العربية في تطوير المفردات لغير الناطقين بها Jurnal Ilmu Tarbiyah; Vol 5 No 1 (2016): January 2016. Retrieved from http://ejournal.stitmuhpacitan.ac.id/index.php/tajdid/article/view/15 